\title{
Differential Target-Dependent Actions of Coexpressed Inhibitory Dynorphin and Excitatory Hypocretin/ Orexin Neuropeptides
}

\author{
Ying Li and Anthony N. van den Pol \\ Department of Neurosurgery, Yale University School of Medicine, New Haven, Connecticut 06520
}

\begin{abstract}
The hypocretin/orexin arousal system plays a key role in maintaining an alert wake state. The hypocretin peptide is colocalized with an opioid peptide, dynorphin. As dynorphin may be coreleased with hypocretin, we asked what action simultaneous stimulation with the excitatory neuropeptide hypocretin and the inhibitory peptide dynorphin might exert on cells postsynaptic to hypocretin axons, including hypocretin neurons. Hypocretin neurons received direct synaptic contact from other hypocretin neurons but showed little direct response to hypocretin. Here, we show that mouse hypocretin neurons are acutely sensitive to dynorphin. Dynorphin inhibits the hypocretin system by direct postsynaptic actions (hyperpolarization, decreased spike frequency, increased GIRK (G-protein-gated inwardly rectifying $\mathrm{K}^{+}$channel) current, and attenuated calcium current, and indirectly by reducing excitatory synaptic tone. Interestingly, a selective antagonist of $\kappa$-opioid receptors enhanced activity of the hypocretin system, suggesting ongoing depression by endogenous hypothalamic opioids. Electrical stimulation of hypothalamic microslices that contained hypocretin cells and their axons evoked dynorphin release. Costimulation with dynorphin and hypocretin had three different effects on neurons postsynaptic to hypocretin axons: direct response to only one or the other of the two peptides [hypocretin cells respond to dynorphin, arcuate neuropeptide Y (NPY) cells respond to hypocretin], differential desensitization causing shift from inhibitory current to excitatory current with repeated coexposure (melanin-concentrating hormone neurons), synergistic direct excitation by hypocretin and presynaptic attenuation of inhibition by dynorphin (arcuate NPY neurons). These results suggest that hypocretin neurons may be able to exercise a high degree of modulatory control over postsynaptic targets using multiple neuropeptides with target-dependent actions.
\end{abstract}

Key words: arousal; attention; feeding; lateral hypothalamus; neuroendocrine; sleep

\section{Introduction}

The hypocretin/orexin neurons of the lateral hypothalamus (LH)-perifornical area (de Lecea et al., 1998; Sakurai et al., 1998) promote arousal and attention (Hagan et al., 1999; Sutcliffe and de Lecea, 2002). In the absence of hypocretin or its receptors, animals and humans become narcoleptic (Lin et al., 1999; Nishino et al., 2000; Peyron et al., 2000; Thannickal et al., 2000; van den Pol, 2000). The absence of hypocretin neurons generates a greater level of disturbance to metabolic regulation (greater hypophagia coupled with increased body weight), with some differences in narcolepsy, compared with simple hypocretin peptide loss. This suggests that other substances that hypocretin neurons release also play a functional role in intercellular signaling (Chemelli et al., 1999; Hara et al., 2001, 2005).

Neurons that synthesize the excitatory (de Lecea et al., 1998; van den Pol et al., 1998, 2002; Liu et al., 2002) peptide hypocretin also synthesize the endogenous opioid peptide dynorphin, and a

Received Aug. 4, 2006; revised Nov. 1, 2006; accepted Nov. 6, 2006.

This work was supported by National Institutes of Health Grants NS48476, NS41454, and NS34887. We thank Y. Yang and V. Rogulin for technical assistance.

Correspondence should be addressed to Anthony N. van den Pol, Department of Neurosurgery, Yale University School of Medicine, 333 Cedar Street, New Haven, CT 06520. E-mail: anthony.vandenpol@yale.edu.

D01:10.1523/JNEUROSCI.3380-06.2006

Copyright $\odot 2006$ Society for Neuroscience ～0270-6474/06/2613037-11\$15.00/0 high degree of colocalization is reported (Chou et al., 2001). Hypocretin neurons send widespread axonal efferents to many regions of the brain and spinal cord, including the locus ceruleus, ventral tegmental area, nucleus accumbens, cortex, and midline thalamus, and to other regions of the lateral and medial hypothalamus (Broberger et al., 1998; Elias et al., 1998; Peyron et al., 1998; van den Pol, 1999). Hypocretin cells maintain local axonal collaterals that terminate on other cells in the $\mathrm{LH}$, including hypocretin cells and neurons that synthesize melanin concentrating hormone $(\mathrm{MCH})$. Unlike the nearby $\mathrm{MCH}$ cells that are directly excited by hypocretin (van den Pol et al., 2004), the hypocretin neurons show little direct response to hypocretin (Li et al., 2002); responses to their other peptide, dynorphin, have not been studied previously. Opioid receptors, including the dynorphinsensitive $\kappa$ receptor, have been described in the LH (Mansour et al., 1987; Desjardins et al., 1990, Ding et al., 1996), and immunoreactivity for the morphine-sensitive $\mu$-opioid receptor has been reported in hypocretin cells (Georgescu et al., 2003). That hypocretin cells synthesize both an excitatory peptide, hypocretin, and a peptide that is usually inhibitory, dynorphin, raises an interesting question: why would a single neuron use both an excitatory and inhibitory peptide? The colocalization of peptides is not unique to hypocretin cells; other hypothalamic and nonhypothalamic cells may contain multiple peptides, although they often 
have a similar inhibitory or excitatory valence (Hokfelt et al.,1986; Freund and Buzsaki,1996). Colocalization of excitatory and inhibitory neuropeptides is more unusual, and the possible physiological effects of two hypothalamic modulatory transmitters of opposite action has received little attention.

We used whole-cell recording in mouse hypothalamic brain slices to study the responses of identified hypocretin cells to the endogenous opioid peptide dynorphin, and we further tested whether dynorphin was released in the area of the hypocretin cells. We also examined other neurons postsynaptic to hypocretin neurons, including two cells that participate in the regulation of energy homeostasis, the arcuate nucleus neurons synthesizing neuropeptide Y (NPY) and LH cells synthesizing MCH to address the question as to what cellular physiological action costimulation with an excitatory neuromodulator and inhibitory neuromodulator might generate.

\section{Materials and Methods}

Transgenic mice. Transgenic mice were used that expressed green fluorescent protein (GFP) selectively in hypocretin cells, as confirmed with immunostaining and in situ hybridization (Li et al., 2002; Yamanaka et al., 2003); mice were kindly provided by Dr. T. Sakurai (University of Tsukuba, Tsukuba, Japan). A different line of transgenic mice that expressed GFP in the lateral hypothalamus in neurons that synthesize $\mathrm{MCH}$ was also used in one set of experiments; this mouse has been described previously (van den Pol et al., 2004). A third transgenic mouse [generously provided by Drs. T. Horvath (Yale University) and J. Friedman (Rockefeller University, New York, NY)] expressed GFP selectively in the neurons of the arcuate nucleus that synthesize NPY (Pinto et al. 2004; Roseberry et al., 2004). Experiments were approved by the Yale University Committee on Animal Care and Use.

Dynorphin localization and release. To verify that dynorphin was localized in hypocretin neurons that expressed GFP under control of the hypocretin gene promoter, hypocretin-GFP transgenic mice were heavily anesthetized with sodium pentobarbital and perfused intracardially with $4 \%$ paraformaldehyde; $20 \mu \mathrm{m}$ coronal sections were cut on a cryostat. Immunostaining was done as described previously (van den Pol et al., 1998) using Alexa 594 (1:300) to produce a red immunolabel; primary rabbit anti-dynorphin(1-13) sera (1:6000 dilution) was obtained from Peninsula Labs (San Carlos, CA). The specificity of this antisera has been described previously (Chou et al., 2001). Two mice were given intracerebral injections of colchicine ( $75 \mu \mathrm{g} / \mathrm{kg}$ body weight; $40 \mathrm{~h}$ before they were killed) to block axonal transport of the peptide from the cell body; cell body immunostaining was enhanced by colchicine.

To examine dynorphin release, lateral hypothalamic microslices were maintained in vitro [described by Acuna-Goycolea et al. (2004)] and stimulated electrically to evoke transmitter release. Slice buffer was then collected and tested with an ELISA assay in which the test sample was first adsorbed to wells of 96-well plates and then quantified using dynorphin antisera, followed by goat anti-rabbit immunoglobulin conjugated to horseradish peroxidase. After treatment with diaminobenzidine and hydrogen peroxide, optical density was read in a Dynatech Laboratories (Alexandria, VA) spectrophotometer.

Whole-cell recording. Briefly, 2- to 4-week-old mice were anesthetized with Nembutal $(100 \mathrm{mg} / \mathrm{kg})$ and decapitated, and the brain was quickly removed, trimmed, and mounted on a vibratome in ice-cold and oxygenated artificial CSF (ACSF) that was also used for recording [(in mM): $124 \mathrm{NaCl}, 3 \mathrm{KCl}, 2 \mathrm{CaCl}_{2}, 2 \mathrm{MgCl}_{2}, 1.23 \mathrm{NaH}_{2} \mathrm{PO}_{4}, 26 \mathrm{NaHCO}_{2}, 10$ glucose, $\mathrm{pH} 7.4$, with $\mathrm{NaOH}$ ] and was continuously bubbled with $5 \%$ $\mathrm{CO}_{2}$ and $95 \% \mathrm{O}_{2}$. Coronal hypothalamic slices (250-300 $\mu \mathrm{m}$ thick) containing hypocretin cells were obtained and then incubated for at least $2 \mathrm{~h}$ at room temperature before being transferred into a recording chamber $(0.5-1 \mathrm{ml}$ volume) where the slice was constantly perfused with ACSF. ACSF and drugs were preheated to $32^{\circ} \mathrm{C}$ and constantly bubbled with $5 \% \mathrm{CO}_{2}$ and $95 \% \mathrm{O}_{2}$. The recording chamber was mounted on the stage of an upright microscope (BX51WI; Olympus, Tokyo, Japan) equipped with a $40 \times$ water immersion objective (Olympus).
Whole-cell patch recordings were made from GFP-expressing neurons as described previously ( $\mathrm{Li}$ et al., 2002). The pipette solution contained the following (in mM): $145 \mathrm{KMeSO}_{4}, 1 \mathrm{MgCl}_{2}, 10 \mathrm{HEPES}, 1.1$ EGTA, $2 \mathrm{Mg}$-ATP, $0.5 \mathrm{Na}_{2}$-GTP, adjusted to $\mathrm{pH} 7.3$ with $\mathrm{KOH}$. In experiments on calcium currents, the recorded neuron was clamped at -80 $\mathrm{mV}$ and then given a voltage step to $0 \mathrm{mV}$. During these experiments, the bath solution contained the following (in mM): $100 \mathrm{NaCl}, 40$ TEA-Cl, 2.5 $\mathrm{KCl}, 5 \mathrm{BaCl}_{2}, 10$ HEPES, 10 glucose, and $1 \mu \mathrm{M}$ TTX, $\mathrm{pH}$ adjusted to 7.3 with $\mathrm{KOH}$. The pipette solution contained the following (in $\mathrm{mM}$ ): 135 CsCl, $1 \mathrm{MgCl}_{2}$, 10 HEPES, 5 BAPTA-Cs, 4 Mg-ATP, $0.5 \mathrm{Na}_{2}$-GTP, pH adjusted to 7.3 with $\mathrm{CsOH}$. The current-voltage relationship was tested by injection of a series of constant current pulses (from -200 to $30 \mathrm{pA}$ for $100 \mathrm{~ms}$ with a $20 \mathrm{pA}$ increment, at $2 \mathrm{~s}$ intervals) to the recorded neurons held at resting membrane potential. Series resistance was monitored by the peak amplitude of the capacitive transient induced by a $-5 \mathrm{mV}$ step applied every 4 or $6 \mathrm{~s}$. Neurons in which the series resistance was $>20$ $\mathrm{M} \Omega$ and changed by $>15 \%$ during the experiment were judged unstable and were discarded from the statistics. Inward rectification of GIRK (Gprotein-gated inwardly rectifying $\mathrm{K}^{+}$channel) currents was examined with a ramp pulse from -140 to $-20 \mathrm{mV}$ for $500 \mathrm{~ms}$.

Recordings were made using an EPC-9 amplifier and Pulse 8.5 software (Heka, Lambrecht, Germany). Data were measured using Pulsefit 8.5 and Axograph 4.8 and exported to IgorPro Carbon 4.07 software (WaveMetrics, Lake Oswego, OR) and Kaleida Graph (Synergy Software, Reading, PA) where plots were made and statistical analysis was performed. Drugs were applied by gravity feed either through a large bore flow pipe with an inner diameter of $500 \mu \mathrm{m}$ aimed at the recorded cell or by bath application. To ensure that the recorded cell was in the direct line of flow of the flow pipe, a brief stimulation (5-10 s) with $10 \mu \mathrm{M}$ glutamate was used to demonstrate an excitatory response. Peptide responses were faster and recovery more complete with the flow-pipe application. When drugs were not being applied, a flow of extracellular buffer continued from the flow pipe. Different drugs were maintained in oxygenated form, and lines of the same diameter from the different drugs were designed to meet at a manifold at the recording chamber with multiple inputs and a single flow-pipe output.

EPSCs were recorded at a holding potential of $-60 \mathrm{mV}$. When recording spontaneous EPSCs (sEPSCs), bicuculline $(30 \mu \mathrm{M})$ was added to the bath solution. When recording miniature EPSCs, bicuculline $(30 \mu \mathrm{M})$ and TTX $(0.5 \mu \mathrm{M})$ were added to the bath solution. Only events with amplitudes $>5 \mathrm{pA}$ were counted. This has been described in detail previously (Gao and van den Pol, 1999). Kolmogorov-Smirnoff statistical tests were used to measure the cumulative probability of synaptic events. The statistical test used, except where indicated, was one-way ANOVA. In the text and figures, values are presented as mean $\pm \mathrm{SE}$, and statistical significance was determined using a criterion of at least $p<0.05$. Action potential frequency was analyzed off-line using AxoGraph 4.5. Action potentials were detected by a fixed amplitude template, which was moved along the recorded traces to test for a match.

Drugs. During experiments, drugs were bath applied at the concentrations indicated. Stock solutions for all drugs were prepared and kept frozen and diluted just before flow pipe or bath application. Hypocretin-2 was synthesized by the Stanford University Peptide Facility, and hypocretin-1 was obtained from Phoenix Pharmaceuticals (Belmont, CA). TTX was obtained from Alomone Labs (Jerusalem, Israel). Bicuculline methiodide (BIC), DL-2-Amino-5-phosphonovaleric acid (AP-5), 6-Cyano-7-nitroquinoxaline-2,3-dione (CNQX), [Met5]Enkephalin, dynorphin A Porcine Fragment 1-13, nor-binaltorphimine dihydrochloride (nor-BNI), and H-D-Phe-Cys-Tyr-D-TrpArg-Thr-Pen-Thr- $\mathrm{NH}_{2}$ (CTAP) were obtained from Sigma-Aldrich (St. Louis, MO).

\section{Results}

\section{Dynorphin inhibits hypocretin neurons}

Dynorphin is an opioid peptide that is synthesized by a small number of CNS neurons and, of particular interest, is cosynthesized by neurons that also make hypocretin (Chou et al., 2001). Here, we first examine the responses of hypocretin cells to the two 
A. Dynorphin decreases spike frequency

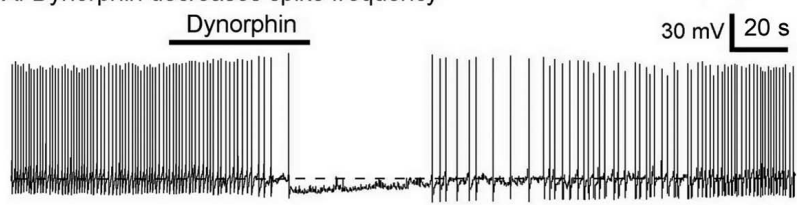

B. Dynorphin decreases spike frequency in a dose-dependent manner

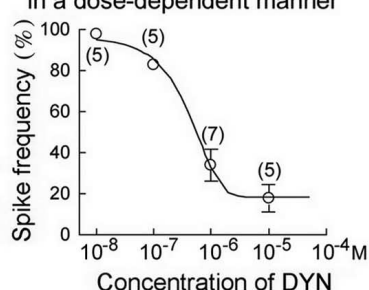

C. Dynorphin hyperpolarizes MP Dynorphin TTX
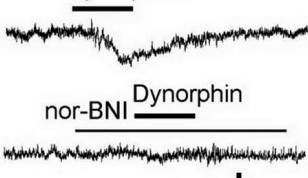
Concentration of DYN

D.

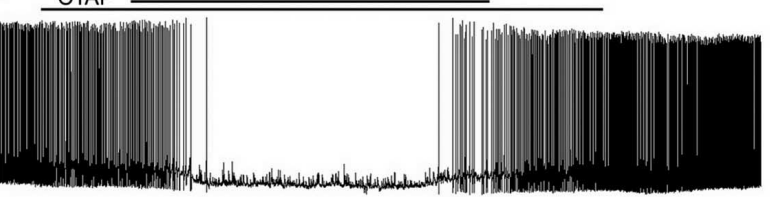

F. Dynorphin activates GIRK

E. Dynorphin on I-V relation
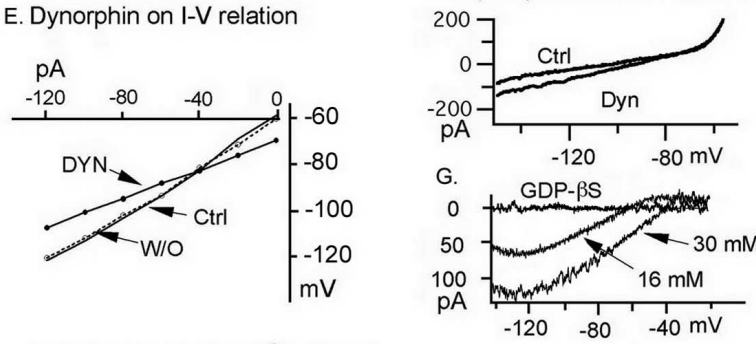

H. Dynorphin inhibits $\mathrm{Ca}^{2+}$ current
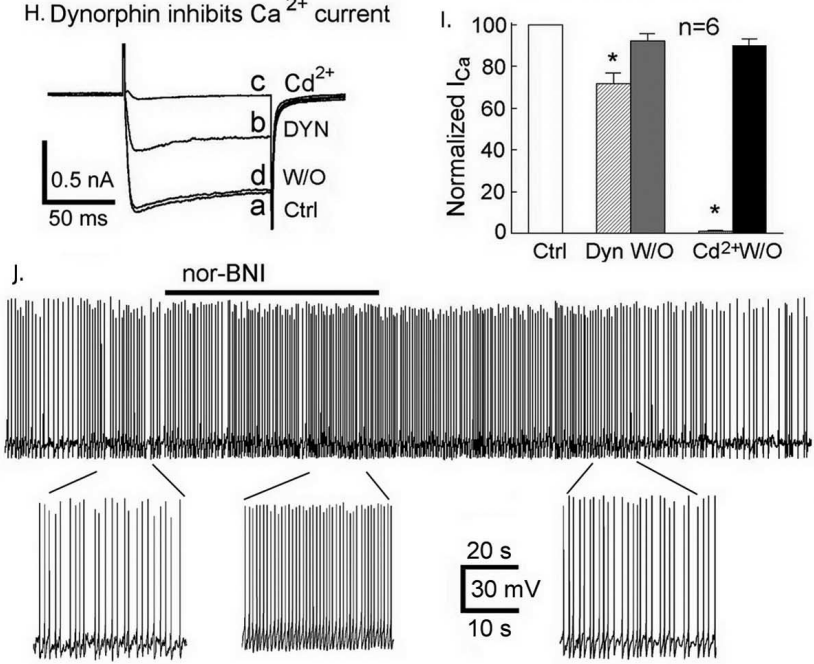

Figure 1. Dynorphin inhibits hypocretin neurons: mechanisms. A, A typical hypocretin neuron showing that flow-pipe application of dynorphin (10 $\mu \mathrm{m})$ decreased spike frequency. $\boldsymbol{B}$, Dynorphin decreased spike frequency in a dose-dependent manner. Dynorphin $(0.01,0.1,1$, and $10 \mu \mathrm{m})$ was applied by flow pipe. $C$, nor-BNI $(1 \mu \mathrm{m})$ blocked dynorphin-induced hyperpoIarization. Top, Dynorphin hyperpolarized membrane potential. Bottom, Pretreatment with $\kappa$-receptor antagonist nor-BNI blocked the dynorphin-mediated hyperpolarization. MP, Membrane potential. D, Dynorphin $(10 \mu \mathrm{m})$ inhibited spikes of hypocretin neurons in the presence of $\mu$ receptor antagonist CTAP $(1 \mu \mathrm{m})$, suggesting that $\mu$ receptors are not responsible for actions of dynorphin on hypocretin cells. $\boldsymbol{E}$, Dynorphin decreases input resistance. $\boldsymbol{F}$, Dynorphinactivated GIRK. Representative current induced by ramp pulse before and during dynorphin application. External potassium concentration was $16 \mathrm{~mm}$. G, The net dynorphin-induced current was potassium and GDP- $\beta$-S dependent. The approximate reversal potential was -90 , -60 , and $-40 \mathrm{mV}$ when external potassium concentration was 3,16 , and $30 \mathrm{~mm}$, respectively. $\boldsymbol{H}$, A typical cell showing that dynorphin $(10 \mu \mathrm{m})$ depressed and $\mathrm{Cd}^{2+}(200 \mu \mathrm{m})$ blocked the $\mathrm{Ca}^{2+}$ current. The letters $\mathrm{a}-\mathrm{d}$ refer to the order of application and proceed in alphabetical peptides, as previous work has shown numerous axonal contacts between hypocretin cells (Broberger et al., 1998; Horvath et al., 1999; Guan et al., 2002). We then study the responses of two other cell types postsynaptic to hypocretin cells: the LH MCH cells and the arcuate NPY cells.

Hypocretin tends to exert excitatory actions on other neurons, including an indirect excitation of other hypocretin neurons ( $\mathrm{Li}$ et al., 2002). In contrast, Figure $1 A$ shows a typical hypocretin cell in which large-diameter flow-pipe application of the opioid peptide dynorphin $(10 \mu \mathrm{M})$ decreased spike frequency recorded in GFP-expressing hypocretin neurons. This inhibitory effect on spike frequency was dose dependent and became progressively more pronounced as concentrations of applied dynorphin were systematically increased $(0.01,0.1,1,10 \mu \mathrm{M})$. A dose-response curve relating spike frequency to dynorphin concentration is shown in Figure $1 B$. Dynorphin also hyperpolarized the membrane potential in a concentration-dependent manner. Dynorphin $(0.1,1$, and $10 \mu \mathrm{M}$, respectively) hyperpolarized membrane potential by $1.4 \pm 0.2 \mathrm{mV}(n=5), 3.4 \pm 0.5 \mathrm{mV}(n=7)$, and $5.2 \pm 0.9 \mathrm{mV}(n=5 ; p<0.05)$. The membrane potential returned to control level after peptide washout.

We next asked whether the dynorphin-mediated inhibition was a result of a direct action on hypocretin neurons, examining the effect of dynorphin on membrane potential in the presence of TTX $(0.5 \mu \mathrm{M})$ to block spike-mediated synaptic transmission. Dynorphin $(10 \mu \mathrm{M})$ hyperpolarized the membrane potential by $4.4 \pm 0.7 \mathrm{mV}(n=18 ; p<0.05)$ (Fig. $1 C)$. After washout, the membrane potential returned to the control level. Dynorphin actions are mediated primarily by the $\kappa$ receptor in other brain regions (Castillo et al., 1996; Ogura and Kita, 2000; Shuster et al., $2000)$. When hypocretin neuron cells were pretreated with the $\kappa$

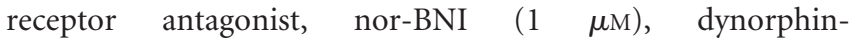
hyperpolarizing actions were blocked $(n=7 ; p>0.05)$ (Fig. $1 C$ ). Bath application of $1 \mu \mathrm{M}$ dynorphin reduced spike frequency by $80 \%(n=6)$, and this effect was blocked with $100 \mathrm{~nm}$ nor-BNI. In contrast, when the hypocretin neurons were pretreated with specific $\mu$-receptor antagonist CTAP $(1 \mu \mathrm{M})$, dynorphin still blocked spike frequency and hyperpolarized membrane potential (ANOVA; $p<0.05 ; n=6$ ) (Fig. $1 D$ ). The same concentration of CTAP, however, was effective in blocking the hyperpolarizing actions of the $\mu$ receptor agonist, met-ENK (100 $\mu \mathrm{M}$; data not shown). These data suggest that dynorphin directly inhibits hypocretin cells by activating a $\kappa$ receptor.

To determine whether dynorphin-induced inhibition was based on a change in ion channel conductance, a step pulse of current was performed under current clamp. Dynorphin $(10 \mu \mathrm{M})$ reduced the input resistance from a pretreatment level of $408 \pm$ 26 to $334 \pm 28 \mathrm{M} \Omega(n=7 ; p<0.05)$ (Fig. $1 E)$, suggesting ion channels were opened by dynorphin.

Other inhibitory peptides such as neuropeptide $Y$ can depress the activity of hypocretin cells by activation of a GIRK current (Fu et al., 2004), and opioid peptides have been shown previously to increase potassium currents in other neurons (Alreja and Aghajanian, 1993; Grudt and Williams, 1993; Svoboda and Lupica, 1998). To test whether GIRK currents were activated by dynorphin, currentvoltage curves were obtained using a voltage ramp from -140 to $-20 \mathrm{mV}$ in the presence of TTX to block spikes, AP- 5 and CNQX to

order. $I$, A bar graph showing that dynorphin $(10 \mu \mathrm{m})$ decreased $\mathrm{Cd}^{2+}$-blockable $\mathrm{Ca}^{2+}$ current. DYN, Dynorphin; W/0, washout; Ctrl, control.J, $\kappa$ receptor antagonist nor-BNI $(1 \mu \mathrm{M})$ increased spike frequency. 
block ionotropic glutamate receptors, and BIC to block GABA receptors. The protocol details used to study the GIRK current were described previously (Fu et al., 2004). Dynorphin $(10 \mu \mathrm{M})$ induced an inwardrectified current $(n=12)$ (Fig. $1 F)$. In $3 \mathrm{~mm}$ potassium, the current reversed at $-89 \mathrm{mV}$. When external potassium concentration was increased from 3 to $16 \mathrm{~mm}$ or $30 \mathrm{mM}$, the reversal potential was -58 or $-40 \mathrm{mV}$, respectively, the potential predicted by the Nernst equation for the potassium reversal potential $(n=12)$ (Fig. $1 G)$. When the Gprotein blocker-nonhydrolyzable GDP ana$\log$ GDP- $\beta$-S $(800 \mu \mathrm{M})$ was added into the pipette solution, dynorphin $(10 \mu \mathrm{M})$ failed to induce an inward-rectified potassium current $(n=5)$, suggesting a G-protein dependence.

To test whether dynorphin exerts an effect on calcium currents as has been reported in other cells (Wiley et al., 1997), cells were subjected to a step depolarization from -80 to $0 \mathrm{mV}$ in the presence of TTX $(0.5 \mu \mathrm{M}), \operatorname{AP}-5(50 \mu \mathrm{M})$, CNQX (10 $\mu \mathrm{M})$, and BIC $(30 \mu \mathrm{M})$ and cesium in the pipette to block potassium channels. Dynorphin $(10 \mu \mathrm{M})$ decreased the $\mathrm{Ca}^{2+}$ current by $28 \pm 26 \%(n=6$; $p<0.05)$ (Fig. $1 H$ ), and the current recovered after washout of the peptide. The current was reversibly blocked by the calcium channel blocker cadmium (200 $\mu \mathrm{M})$ (Fig. 1I), consistent with it being a calcium current (Sun et al., 2001).

\section{Tonic ongoing inhibition by}

endogenous opioids

To determine whether dynorphin might be spontaneously released onto hypocretin neurons, we applied the selective $\kappa$ receptor antagonist nor-BNI $(1 \mu \mathrm{M})$ by itself. In the absence of any exogenous dynorphin added experimentally, norBNI increased the spike frequency by $33.7 \pm 7.5 \%(n=9 ; p<0.05)$ (Fig. $1 J)$. After washout, the spike frequency returned to control levels. These data suggest that an endogenous $\kappa$ receptor agonist acts to reduce the activity of hypocretin neurons; that agonist may be dynorphin released from hypocretin neurons in the slice.

Dynorphin attenuates excitatory synaptic input by presynaptic mechanism

To test whether the decrease in the activity of hypocretin cells might be a result of an attenuation of excitatory synaptic input to the cells, we examined the effect of dynorphin on EPSCs, recorded in voltage clamp at $-60 \mathrm{mV}$ holding potential. Spontaneous EPSCs were recorded while the hypocretin cells were pretreated with BIC $(30 \mu \mathrm{M})$. Dynorphin $(10 \mu \mathrm{M})$ decreased the frequency of sEPSC by $39.0 \pm 3.5 \%(n=9 ; p<0.05)$ (Fig. $2 A, B)$, and the frequency of sEPSC returned to $78.8 \pm 3.5 \%$ after peptide

\section{A. Dynorphin decreases sEPSC frequency}
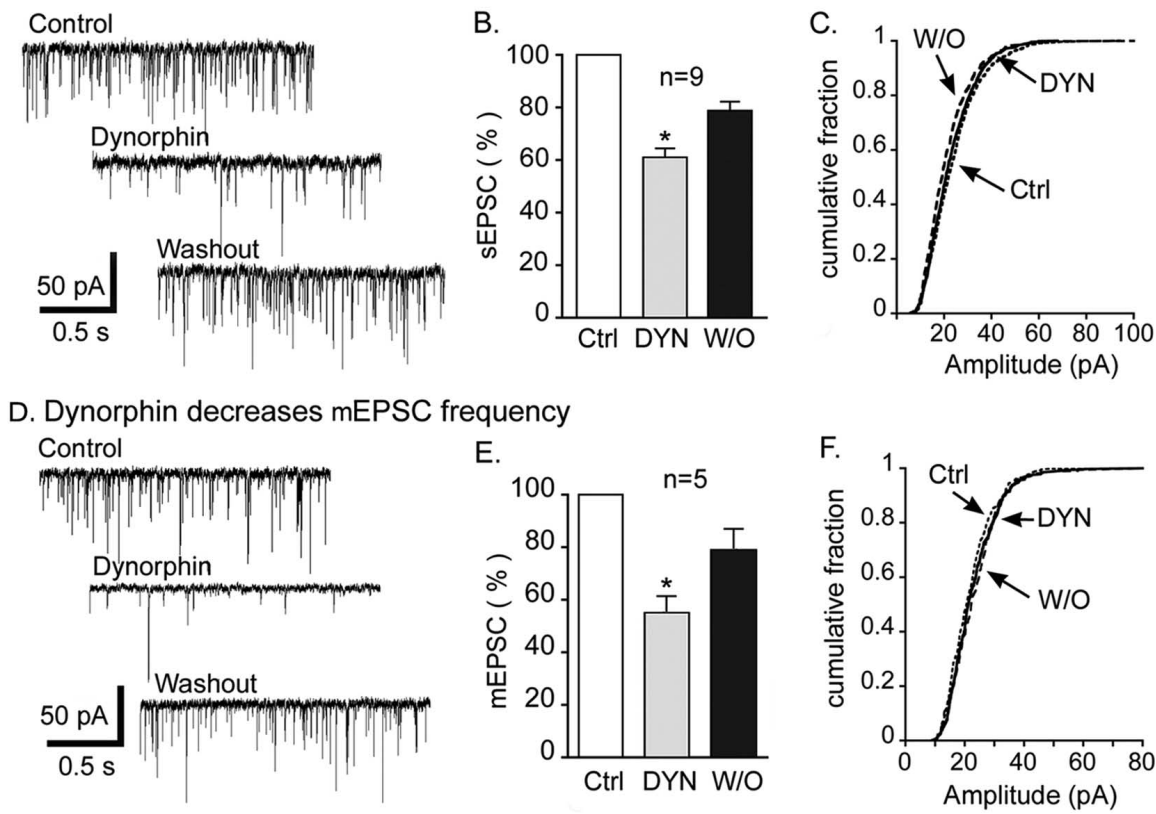

G. Dynorphin inhibits hypocretin response

Control Dyn DYN+Hcrt 1+2 Washout HCRT 1+2 Washout
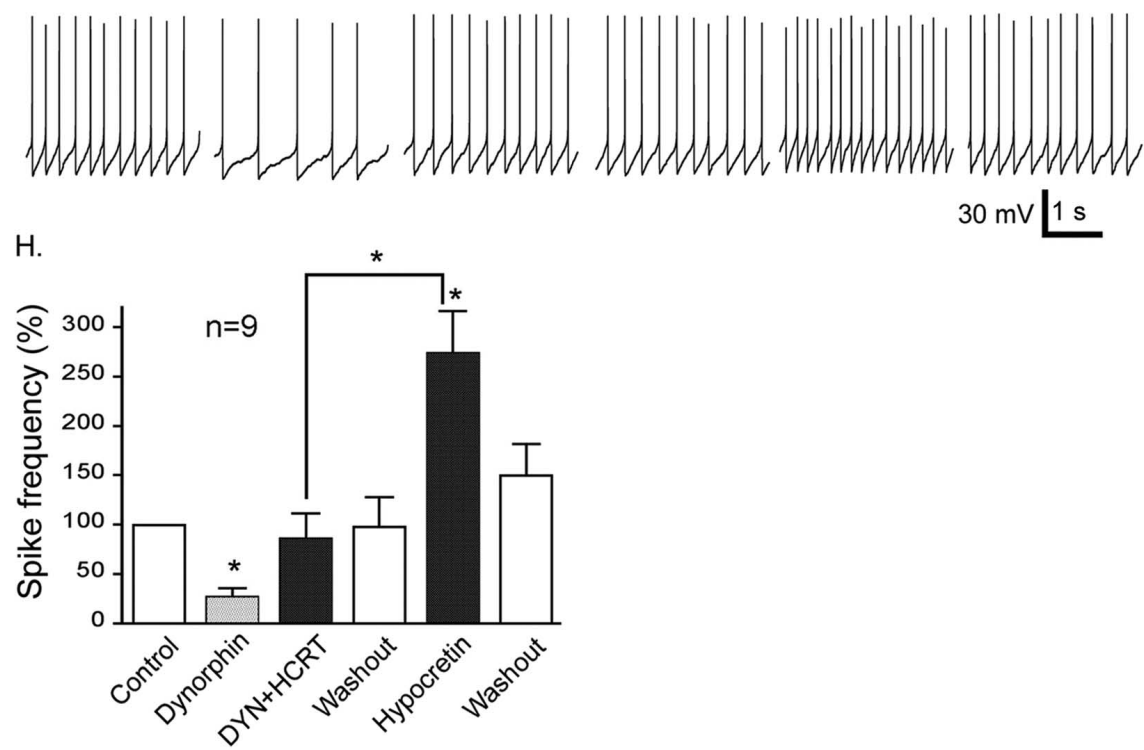

Figure 2. Dynorphin inhibits glutamate release presynaptically. $A$, A representative cell showing that dynorphin (flow pipe, 10 $\mu \mathrm{M}$ ) decreased sEPSC frequency. $\boldsymbol{B}$, Bar graph of dynorphin effect on sEPSC frequency. $\boldsymbol{C}$, Representative cell showing cumulative probability of dynorphin action on the amplitude of $s E P S C S$. D. Typical cell showing dynorphin decreases mEPSC frequency. $\boldsymbol{E}$, Bar graph showing that dynorphin decreased mEPSC frequency $(n=5 ; p<0.05)$. $F$, A typical cell where dynorphin (10 $\mu \mathrm{m})$ did not change the amplitude of mEPSCs. G, A representative cell in which dynorphin $(10 \mu \mathrm{m})$ depressed activity and thus could block a hypocretin-induced increase in spike frequency. $\boldsymbol{H}, \mathrm{A}$ bar graph summarizing group data demonstrating that the hypocretininduced increase in spike frequency was not found in the presence of dynorphin. DYN, Dynorphin; W/0, washout; Ctrl, control. washout. Application of the glutamate receptor antagonists AP-5 $(50 \mu \mathrm{M})$ and CNQX $(10 \mu \mathrm{M})$ blocked the EPSCs.

Miniature EPSCs were recorded as the cell was perfused with BIC $(30 \mu \mathrm{M})$ to block GABA-mediated synaptic activity and TTX $(0.5 \mu \mathrm{M})$ to block spikes. Dynorphin $(10 \mu \mathrm{M})$ decreased the frequency of mEPSCs by $45 \pm 6.4 \%(n=5 ; p<0.05)$ (Fig. $2 D, E)$, and the frequency of mEPSCs recovered to $79 \pm 8 \%$ after peptide washout. Dynorphin did not change the amplitude of mEPSCs (Kolmogorov-Smirnoff test; $p>0.05$ ) (Fig. $2 F$ ). Application of 
the glutamate receptor antagonists AP-5 (50 $\mu \mathrm{M})$ and CNQX (10 $\mu \mathrm{M})$ blocked the mEPSCs. Together, these data support the view that dynorphin inhibits glutamate release by presynaptic actions on receptors on the excitatory axon terminals.

Dynorphin reduces excitatory response to hypocretin

We showed previously that hypocretin indirectly enhanced the activity of hypocretin cells by increasing the excitatory synaptic tone ( $\mathrm{Li}$ et al., 2002). Here, we tested the combined effect of dynorphin and hypocretin on hypocretin cells. In the presence of dynorphin $(10 \mu \mathrm{M})$ for $3 \mathrm{~min}$, the spike frequency was decreased to $27 \pm 9 \%$ of control. When both hypocretin 1 plus 2 together ( 1 $\mu \mathrm{M}$ each) were applied in the presence of dynorphin, the spike frequency was only reduced to $86 \pm 26 \%$ of the control $(n=9$; $p>0.05$ ) (Fig. 2G). The spike frequency returned to the control level after washout. When hypocretin 1 plus 2 were applied without dynorphin, the spike frequency was increased to $274 \pm 43 \%$ $(p<0.05)$ (Fig. 2G,H). Thus, dynorphin caused a large and statistically significant decrease in the excitatory response of hypocretin cells to hypocretin (ANOVA; $p<0.05$ ).

\section{Dynorphin release from lateral hypothalamus}

To verify that GFP-expressing hypocretin neurons also contained dynorphin, we used Texas Red immunostaining with a rabbit antidynorphin antibody. As reported previously with parallel double immunostaining (Chou et al., 2001), hypocretin neurons that expressed GFP also were immunoreactive for dynorphin. Almost all neurons $(95 \%+)$ that were immunoreactive for dynorphin were also GFP positive. Figure 3, $A$ and $B$, shows red dynorphin immunostaining in GFP-positive hypocretin neurons.

To determine whether dynorphin was released from the hypothalamic region where hypocretin cells and axons are found, miniature brain slices, which only contained the dorsal lateral hypothalamus area, were prepared (Acuna-Goycolea et al., 2004). Because of the small volume of tissue, a single slice was not large enough to detect a reliable signal; for this reason, we pooled microslices from several animals for each set of experiments. A total of 10 slices with $\sim 350 \mu \mathrm{m}$ thickness from five mice (two left and two right lateral hypothalamic slices from five mice) were perfused in a 250 - $\mu$ l-volume chamber in each set of five experiments (total mice, 25). Slices were allowed to recover from sectioning for $90 \mathrm{~min}$ after cutting, similar to that period used before recording. Field electrical stimulation $(10 \mathrm{~Hz}, 5 \mathrm{~ms}, 20 \mathrm{~V}$, for a total $3 \mathrm{~min}$ ) was used to stimulate neurotransmitter release. Fluid $(200 \mu \mathrm{l})$ was collected from the chamber before, immediately after stimulation, and after recovery. Between each of the three collection periods, buffer was perfused through the chamber. An ELISA test was done on these samples using dynorphin antibody. The optical density of the sample was normalized with serum control. Stimulation caused a dynorphin increase to $126 \pm 11 \%$ of control levels (ANOVA; $p<0.05 ; n=8$ ) (Fig. 3C). The dynorphin release reduced to $112 \pm 7 \%$ of the control after recovery. A second round of electrical stimulation increased dynorphin release to $156 \pm 15 \%$ of the control (ANOVA; $p<0.05 ; n=4$ ) (Fig. $3 C)$. This recovered to $124 \pm 13 \%$ of the control after electrical stimulation ceased.

\section{Hypocretin neurons desensitize faster to dynorphin than to hypocretin}

Hypocretin $(1 \mu \mathrm{M})$ was applied by flow pipe for $2.5 \mathrm{~min}$, and the spike frequency was $223 \pm 28 \%(n=7$; ANOVA; $p<0.05)$ (Fig. $4 A, B)$ of control. No densensitization was found. After peptide washout, the spike frequency returned to $105 \pm 26 \%$. In contrast,
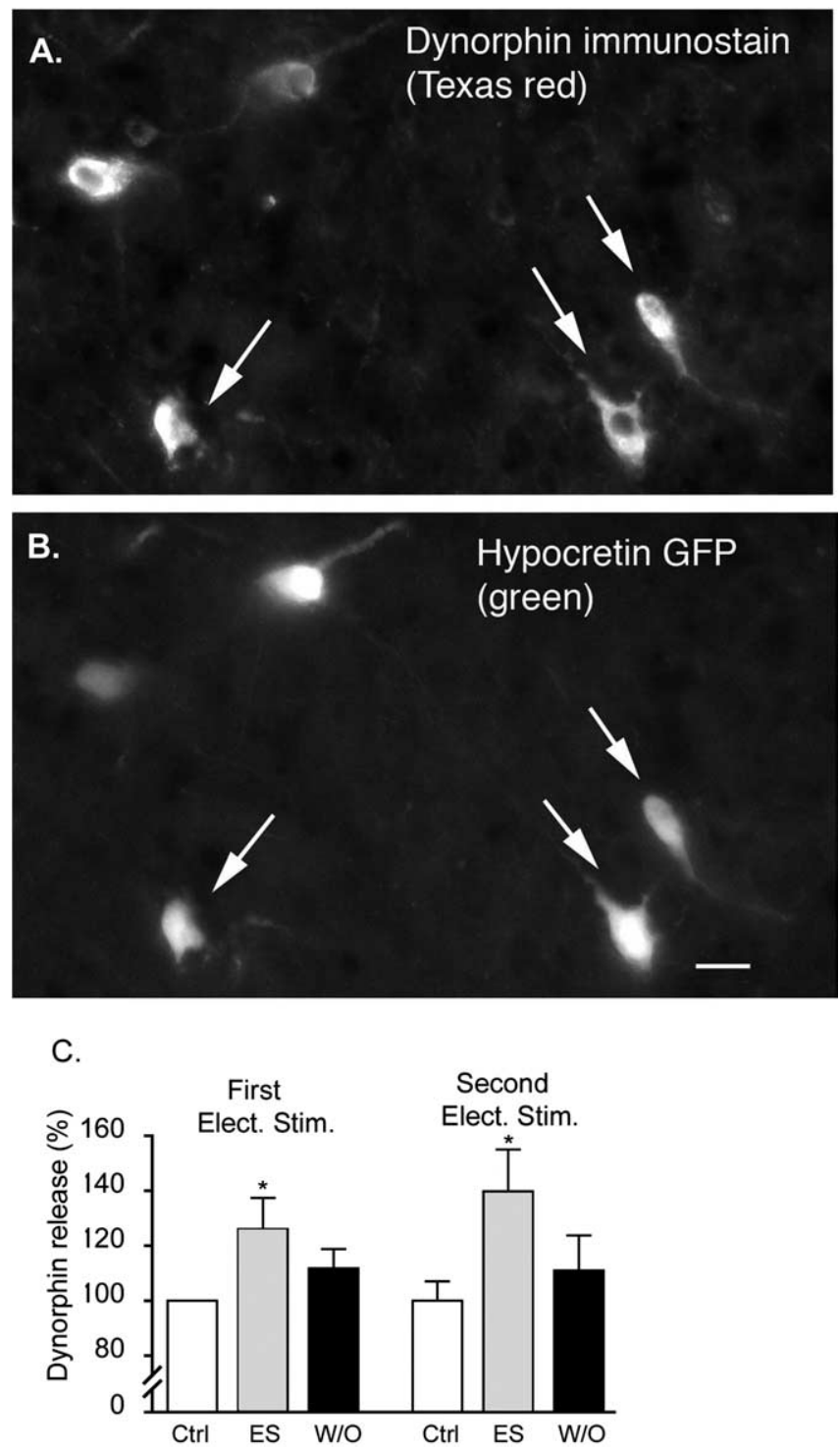

Figure 3. Dynorphin release from dorsal lateral hypothalamus. $\boldsymbol{A}$, Photomicrograph of dynorphin immunostaining using Texas Red. Three arrows indicate immunoreactive cells. $\boldsymbol{B}$ Same cells also express GFP driven by hypocretin promoter. Three arrows indicate GFP-positive hypocretin neurons. Scale bar, $20 \mu \mathrm{m}$. C, ELISA results showing that electrical field stimulation (Elect. Stim.) increased dynorphin release from microslices of dorsal lateral hypothalamus. Ctrl, Control; ES, electrical stimulation; $\mathrm{W} / 0$, recovery washout. ${ }^{*} p<0.05$.

when an equimolar concentration of dynorphin $(1 \mu \mathrm{M})$ was applied for the same 2.5 min interval, the spike frequency decreased to a minimum of $37 \pm 22 \%$ of the control $(n=6$; ANOVA; $p<$ 0.05 ) (Fig. 4C,D). However, after the first $90 \mathrm{~s}$ of dynorphin application, spike frequency began to recover spontaneously in the ongoing presence of dynorphin. The spike frequency rose to $84 \pm$ $20 \%$ of the control by the end of the $2.5 \mathrm{~min}$ application and then returned to $98 \pm 17 \%$ of the control after peptide washout.

As the change in membrane potential or spike frequency appears greater for hypocretin than for an equimolar concentration of dynorphin, we increased the dynorphin concentration to approximate the magnitude of the actions of hypocretin. In this new experiment, flow-pipe application of hypocretin $(1 \mu \mathrm{M})$ resulted in a continuously increasing spike frequency of hypocretin neurons to $196 \pm 9 \%$ (ANOVA; $p<0.05 ; n=6$ ) at the end of 2 min application. The spike frequency returned to $109 \pm 11 \%$ of the 
control after washout. The membrane potential was depolarized by $10.5 \pm 2.5 \mathrm{mV}$ by hypocretin (ANOVA; $p<0.05 ; n=6$ ) and then returned to control level after washout. In contrast, during a $2 \mathrm{~min}$ dynorphin $(5 \mu \mathrm{M})$ application, a $4 \pm 0.9$ $\mathrm{mV}$ hyperpolarization was found, and the spike frequency reached a maximum decrease $(85 \pm 11 \%$ decrease $)$ after 1 min of dynorphin (ANOVA; $p<0.05 ; n=8$ ). However, even in the continued presence of dynorphin, spike frequency began to return toward control levels during the second minute of dynorphin application.

We repeated this experiment with a third set of cells using bath application and longer exposure $(6 \mathrm{~min})$ to the peptides. When dynorphin $(1 \mu \mathrm{M})$ was applied for $6 \mathrm{~min}$, the spikes were initially blocked completely (ANOVA; $p<0.05 ; n=8$ ) (Fig. $4 E, F$ ), but then in the continuing presence of dynorphin, the firing rate spontaneously recovered to $70 \pm 11 \%$ of predynorphin control levels. The spike frequency was $80 \pm 15 \%$ of the control after dynorphin washout. In contrast, hypocretin $(0.2 \mu \mathrm{M})$ led to a continuing increase in spike frequency, reaching a maximum of $240 \pm 30 \%$ by the end of the $6 \mathrm{~min}$ application (ANOVA; $p<0.05 ; n=7$ ) (Fig. $4 G, H)$. Spike frequency recovered to $138 \pm$ $12 \%$ after hypocretin washout. These data corroborate the view that dynorphin responses desensitize more rapidly than hypocretin responses in hypocretin cells.

Because hypocretin and dynorphin may be coreleased at the same axon terminal, we asked what the effect of coapplication of the two peptides would be. Hypocretin $(500 \mathrm{nM})$ plus dynorphin $(5 \mu \mathrm{M})$ were applied by flow pipe three times in succession to hypocretin cells $(n=10)$ in current clamp. The first coapplication caused a decrease in spike frequency, but the second and third caused an increase in spike frequency (Fig. 4I). These data are consistent with the more rapid desensitization to dynorphin, with successive coapplications allowing the excitatory hypocretin action to dominate.

\section{Hypocretin excitation prevails over dynorphin inhibition after repeated coexposure in target $\mathrm{MCH}$ neuron}

To test the hypothesis that other target neurons may show differential desensitization to the two peptides, allowing one to prevail over the other in times of enhanced release, we studied the actions of each peptide separately, and then both together, on another neuron of the lateral hypothalamus, the MCH cell. These cells receive direct synaptic input from hypocretin neurons and, unlike hypocretin neurons,
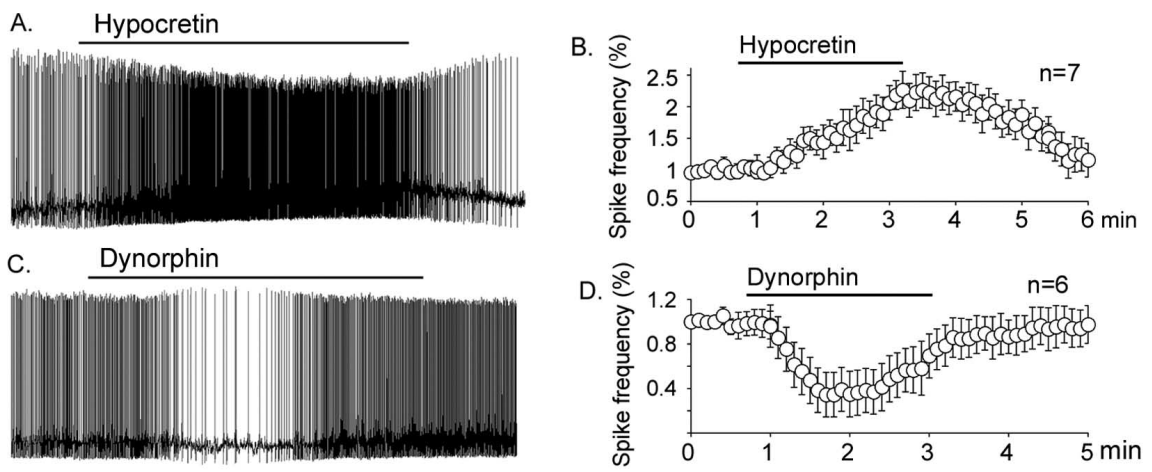

E. Dynorphin
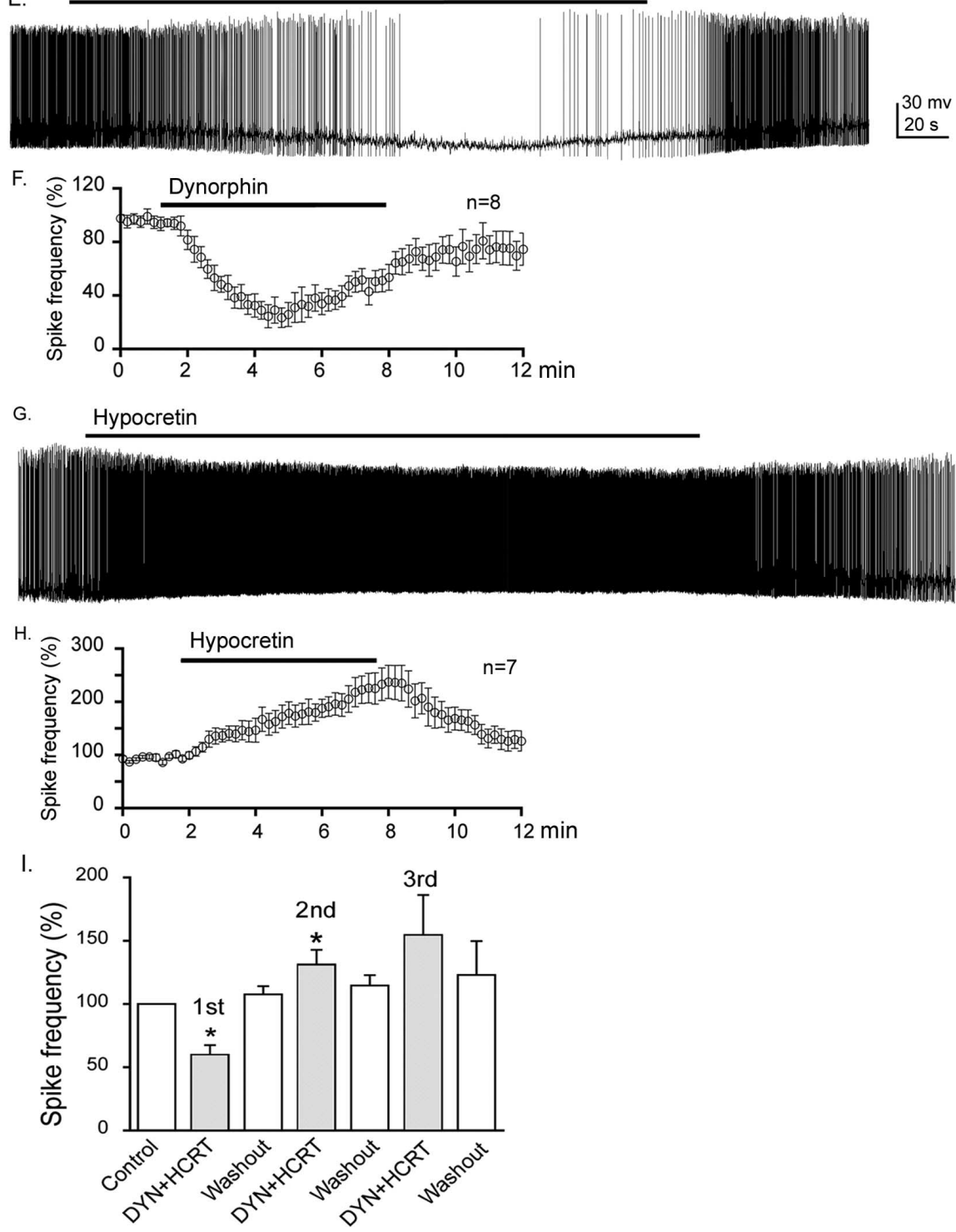

Figure 4. Dynorphin desensitization. $\boldsymbol{A}$, Under current clamp, hypocretin (1 $\mu \mathrm{m})$ increased spike frequency continuously during $2.5 \mathrm{~min}$ of flow pipette application without desensitization. $\boldsymbol{B}$, The mean response to hypocretin of seven hypocretin neurons over time. $\boldsymbol{C}$, In contrast, before the end of a similar $2.5 \mathrm{~min}$ application of dynorphin (1 $\mu \mathrm{M})$, substantial desensitization is shown. $\boldsymbol{D}$, The mean response to dynorphin of six hypocretin neurons. $\boldsymbol{E}$, A typical trace showing dynorphin desensitizes during 6 min bath application. $\boldsymbol{F}$, A mean response ( $n=8$ cells) to dynorphin application. The graph shows the group data. $\mathbf{G}$, Hypocretin $(200 \mathrm{~nm})$ increased spike frequency until the end of application. $\boldsymbol{H}$, The mean $(n=7)$ response to hypocretin application. The graph shows the group data. Little desensitization is shown. $I$, Hypocretin (HCRT) and dynorphin (DYN) were coapplied to hypocretin neurons in current clamp. The bar graph shows the spike responses to three coapplications (gray bars). The other bars show control and recovery. The first coapplication reduced spike frequency, whereas later coapplications increased spike frequency. 
$\mathrm{MCH}$ neuron

A.
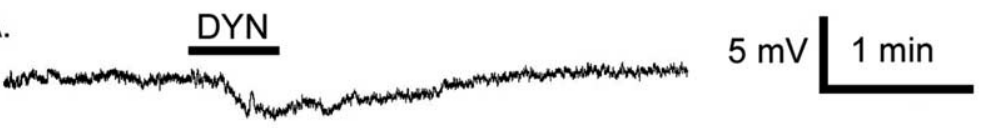

B.

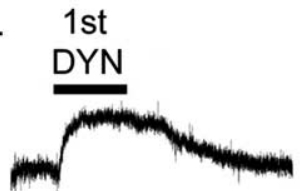

C.

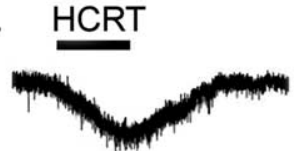

D. DYN+HCRT
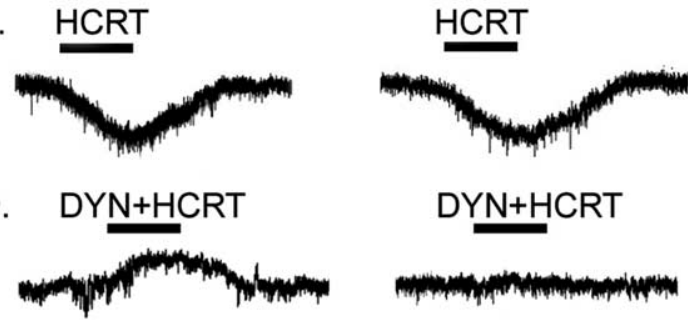

\section{2nd}

DYN

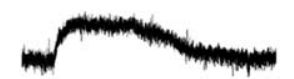

E.

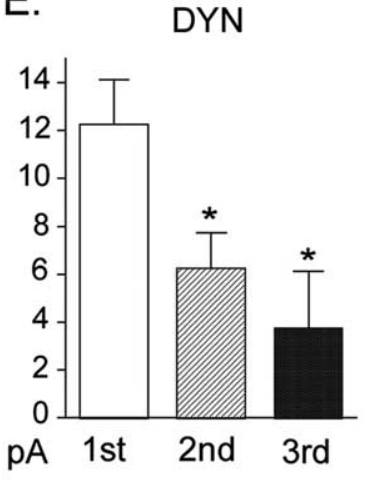

F.

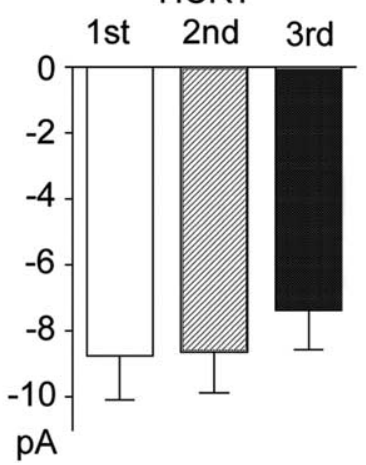

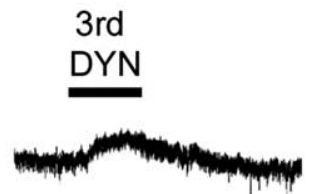
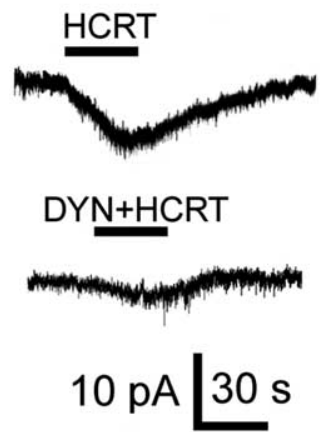

G. DYN+HCRT

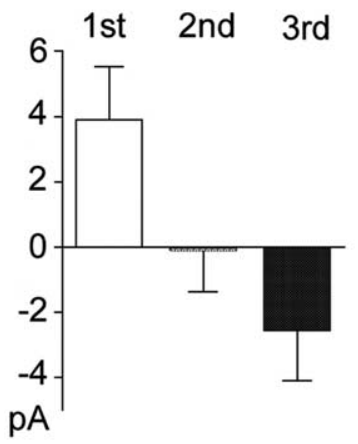

Figure 5. Lateral hypothalamic MCH neurons: dynorphin responses desensitize faster than hypocretin responses. $\boldsymbol{A}$, Flow-pipe application of dynorphin $(10 \mu \mathrm{m})$ hyperpolarizes the membrane potential of an MCH neuron. $\boldsymbol{B}$, The outward current evoked by dynorphin application desensitizes with repeated application (30 s followed by a 2 min recovery). $\boldsymbol{C}$, The inward current in response to hypocretin $(1 \mu \mathrm{m})$ application shows little or no desensitization in this example neuron. See $\boldsymbol{F}$ for group data. $\boldsymbol{D}$, Coapplication of dynorphin and hypocretin shifts from an outward current to an inward current with repeated coapplication from a single flow pipe. $\boldsymbol{E}$, Bar graph shows the attenuation of outward current with repeated application of dynorphin ( $n=6$ neurons). $\boldsymbol{F}$, Bar graph shows the minimal desensitization with repeated application of hypocretin ( $n=8$ neurons). $\mathbf{G}$, Multiple coapplications of dynorphin (DYN) and hypocretin (HCRT) reverse from inducing an outward current to inducing an inward current $(n=11)$. Data are means \pm SEM.

show a direct excitatory response to hypocretin exposure (van den Pol et al., 2004). MCH neurons appear to play a key role in regulating energy homeostasis and may also influence states of anxiety (Borowsky et al., 2002; Seeley and Woods, 2003). We tested whether MCH cells respond to dynorphin, because opioid responses have not been previously studied in these cells. $\mathrm{MCH}$ cells were detected by their expression of GFP in transgenic mice described previously (van den Pol et al., 2004). Under current clamp, flow-pipe application of dynorphin $(10 \mu \mathrm{M})$ hyperpolarized the membrane potential of $\mathrm{MCH}$ cells. Figure $5 \mathrm{~A}$ is a typical trace showing this inhibitory effect of dynorphin on an $\mathrm{MCH}$ cell.

Under voltage clamp, $\mathrm{MCH}$ neurons were tested in the presence of TTX $(0.5 \mu \mathrm{M}), \mathrm{AP}-5(50 \mu \mathrm{M})$, CNQX $(10 \mu \mathrm{M})$, and BIC $(30 \mu \mathrm{M})$ to block synaptic actions. Dynorphin $(10 \mu \mathrm{M})$ or hypocretin $(1 \mu \mathrm{M})$, used at concentrations that gave approximately similar magnitude changes in current, was applied for $30 \mathrm{~s}$ and then washed out for 2 $\min$. This was repeated three times at -60 $\mathrm{mV}$. After the first application, dynorphin $(10 \mu \mathrm{M})$ induced an outward current of at least 5 pA in six neurons (mean, $12.3 \pm 1.9$ $\mathrm{pA}$ ), and these cells were tested with subsequent exposure to dynorphin. The outward current was reduced to $6.2 \pm 1.5 \mathrm{pA}$ when dynorphin was applied a second time 2 min later. The outward current was only $3.8 \pm 2.4 \mathrm{pA}$ when dynorphin was applied a third time (Fig. $5 B, E$ ). There was a significant difference in amplitude between the first and secondary applications of dynorphin (ANOVA test; $p<$ $0.05)$. In contrast, hypocretin $(1 \mu \mathrm{M})$ induced an inward current of $8.8 \pm 1.3 \mathrm{pA}$ $(n=8)$ at the first application. The inward current was $8.6 \pm 1.3$ and $6.5 \pm 1.2 \mathrm{pA}$ when hypocretin was applied a second and a third time at 2 min intervals (Fig. $5 C, F$ ). There was no significant difference in amplitude between the first, second, and third applications of hypocretin (ANOVA test; $p>0.05)$.

As both hypocretin and dynorphin activate receptors on the $\mathrm{MCH}$ cell body and show different rates of desensitization, we next tested the hypothesis that the response to dynorphin would attenuate more than that to hypocretin after repeated coexposure. When dynorphin and hypocretin were applied together at the concentrations used above, the current was initially an outward current of $4.0 \pm$ $1.6 \mathrm{pA}$ with the first application $(n=11)$ (Fig. $5 D, G$ ). This changed to an inward current of $-0.1 \pm 1.3 \mathrm{pA}$ with the second application, and a greater inward current after the third coapplication, $-2.5 \pm 1.5$ $\mathrm{pA}$, a statistically significant shift (ANOVA; $p<0.05$ ). Thus, although the responses to each peptide desensitized with repeated application, the attenuation was significantly greater for the $\kappa$ receptor than for the hypocretin receptor. Thus, release of both peptides might initially include a greater inhibitory contribution from dynorphin, but with repeated exposure might lean more toward the hypocretinmediated excitatory response.

\section{Hypocretin and dynorphin-synergistic actions in target neuropeptide Y neurons}

Hypocretin axons project to the arcuate nucleus where they make direct synaptic contact with neurons that synthesize NPY (Peyron et al., 1998; Horvath et al., 1999). These arcuate nucleus NPY neurons may function to increase energy balance by facilitating food intake (Schwartz et al., 2000; Seeley and Woods, 2003). To test the hypothesis that hypocretin and dynorphin corelease could exert direct and indirect actions, respectively, that would both be excitatory, we recorded arcuate NPY cells from slices of NPY-GFP transgenic mice. Hypocretin application $(1 \mu \mathrm{M})$ in- 
creased spike frequency by $88.8 \pm 21 \%$ $(n=6 ; p<0,05)$ in current clamp (Fig. $6 A$ ), as suggested previously in rat (van den Top et al., 2004) and mouse (AcunaGoycolea and van den Pol, 2005). In voltage clamp, in the presence of TTX, BIC, AP-5, and CNQX to block synaptic activity, hypocretin evoked an inward current $(16 \pm 1.4 \mathrm{pA} ; n=5)$ (Fig. $6 \mathrm{~B})$, supporting the view that hypocretin exerted a direct excitatory effect on NPY neurons. We then asked whether dynorphin might attenuate the GABA input to the NPY neuron, thereby reducing synaptic inhibition. Dynorphin $(2 \mu \mathrm{M})$ reduced the frequency of spontaneous bicuculline-blockable IPSCs by $72 \pm 6 \%(n=6$; $p<0.05)$ (Fig. $6 C, D)$. In the presence of TTX $(0.5 \mu \mathrm{M})$ to block spike-mediated transmitter release and AP-5 $(50 \mu \mathrm{M})$ plus CNQX $(10 \mu \mathrm{M})$ to block EPSCs, miniature IPSCs (mIPSCs) were studied. Dynorphin $(2 \mu \mathrm{M})$ caused a statistically significant reduction in the frequency of mIPSCs $(37.3 \pm 7 \%$ of the control; $n=7 ; p<0.05$ ) (Fig. $6 E, F$ ) without altering the amplitude (KolmogorovSmirnov test; $p>0.05$ ) (Fig. 6G), suggesting a presynaptic mechanism of dynorphin action. Dynorphin at this concentration had little detectable direct effect on the NPY cell. Thus, in a neuron postsynaptic to potential corelease of hypocretin plus dynorphin, hypocretin would excite the cell by direct postsynaptic actions, and dynorphin could also increase excitation of the NPY cell by presynaptically attenuating GABA inhibition.

\section{Discussion}

The data presented here show that neurons of the hypothalamic hypocretin arousal system are inhibited by the endogenous opioid dynorphin that is coexpressed in hypocretin neurons. Dynorphin depressed the spike frequency and hyperpolarized the membrane potential by direct actions on hypocretin neurons that include activation of GIRK-like currents and reduction in calcium currents and by presynaptic attenuation of glutamate release. Hypocretin neurons appear to be under tonic inhibitory modulation by dynorphin, as a $\kappa$ receptor antagonist increased spike frequency. Coexposure to hypocretin and dynorphin elicited different effects, depending on the identity of the hypocretin target neuron.

\section{Dynorphin inhibits hypocretin neurons}

Hypocretin-containing axons terminate in the LH and make synaptic contact with other hypocretin neurons (Broberger et al., 1998; Horvath et al., 1999; Guan et al., 2002), suggesting that these neurons may respond to transmitters they release. Although no direct response to hypocretin is found in hypocretin
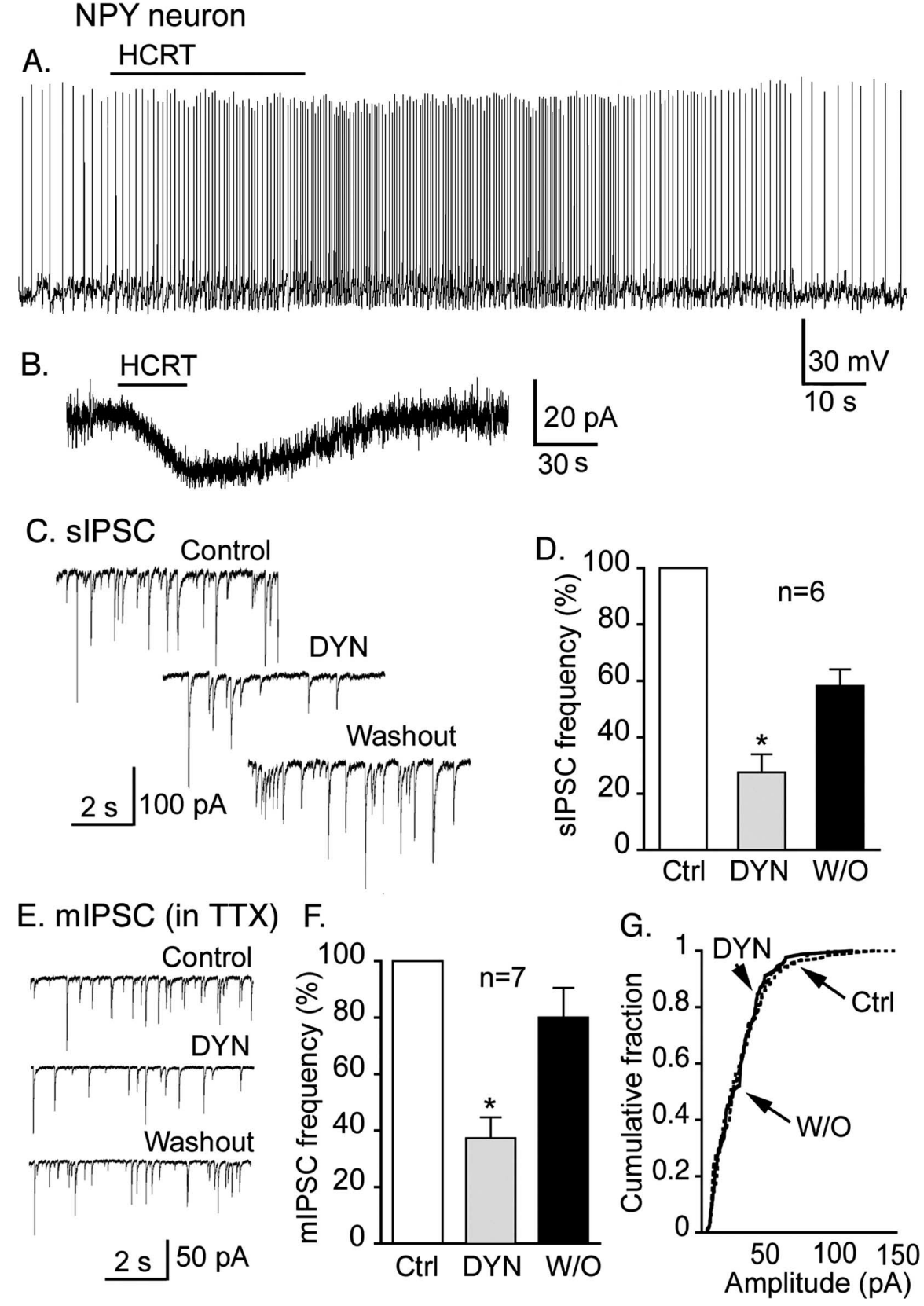

Figure 6. Arcuate nucleus NPY neurons: synergistic responses to hypocretin and dynorphin. $A$, A representative trace showing that hypocretin $(1 \mu \mathrm{m})$ increases spike frequency of an NPY neuron under current clamp. $\boldsymbol{B}$, An example cell showing $1 \mu \mathrm{m}$ hypocretin-induced inward current in the presence of TTX (0.5 $\mu \mathrm{M})$, AP-5 $(50 \mu \mathrm{M})$, CNQX (10 $\mu \mathrm{M})$, and bicuculline (30 $\mu \mathrm{M})$ under voltage clamp. C, A typical cell showing reduction of sIPSC frequency induced by dynorphin (2 $\mu \mathrm{M})$. D, A bar graph showing that dynorphin strongly decreased sIPSC frequency. $\boldsymbol{E}$, A typical cell showing that dynorphin $(2 \mu \mathrm{m})$ decreased the mIPSC frequency. $\boldsymbol{F}$, A bar graph presenting the mean reduction of mIPSC frequency induced by dynorphin. $\mathbf{G}$, The cumulative distribution of mIPSC amplitude was not altered by dynorphin $(2 \mu \mathrm{M})$. DYN, Dynorphin; W/0, washout; Ctrl, control; HCRT, hypocetin.

neurons ( $\mathrm{Li}$ et al., 2002), the opioid peptide dynorphin that is cosynthesized in hypocretin cells in both human and rodent (Chou et al., 2001; Crocker et al., 2005) exerts a substantive and direct inhibition of hypocretin neurons by multiple mechanisms, causing a reduction in spike frequency, hyperpolarization, an activation of GIRK currents, a reduction in calcium currents, and a presynaptic inhibition of synaptic glutamate release. Nor-BNI blocks the direct actions, suggesting they are mediated by $\kappa$ receptors expressed by hypocretin neurons, consistent with previous reports of $\kappa$ receptor expression in the lateral hypothalamus (Mansour et al., 1994, 1996). Of considerable interest, when the $\kappa$ 
receptor antagonist (without exogenous dynorphin) was applied to the slice, an increase in neuronal activity was found. This suggests that hypocretin neurons may be under tonic depression by dynorphin, possibly released by other hypocretin neurons. Hypocretin can enhance the activity of hypocretin cells by increasing release of presynaptic glutamate; this increase is substantially attenuated in the presence of dynorphin. Electrical stimulation evoked release of dynorphin in microslices restricted to the LH area that contains a high number of hypocretin cells and their axon terminals. Cells immunoreactive for dynorphin in these microslices also expressed GFP under control of the hypocretin promoter. Together, these data suggest that axons in the area of the hypocretin cells release dynorphin. There is a good possibility that dynorphin is released by hypocretin cells, although we cannot rule out that severed axons arising from cells outside the microslice (Fallon and Leslie, 1986) might also release the peptide.

Here, we show that hypocretin cells respond to dynorphin with a receptor type consistent with a $\kappa$ receptor; dynorphin actions were blocked by the $\kappa$ receptor antagonist nor-BNI, but not by the $\mu$ antagonist CTAP. In addition, previous work has shown that hypocretin cells may also express a $\mu$-type opioid receptor (Georgescu et al., 2003) and show changes in transcription in the presence of morphine. Together, these data suggest that hypocretin cells respond to opioids through both $\kappa$ and $\mu$ receptors.

It is noteworthy that hypocretin cells contain the opioid peptide dynorphin and appear to be under tonic inhibition that is blocked by opioid receptor antagonists. This raises an interesting question of whether some of the effects of long-term exposure to opiates on cognitive arousal may be a result of a shift in the sensitivity of the hypocretin neurons to the local inhibitory effect of endogenous opioid peptides.

\section{Response to costimulation with inhibitory and excitatory neuromodulator}

What might be the role of an inhibitory neuromodulator such as dynorphin cosynthesized in hypocretin cells? Several possibilities exist, and different permutations occur in different hypocretin target neurons. One possibility is that the postsynaptic target may express receptors for only one of the two peptides; this appears to be the case for hypocretin neurons that respond directly to dynorphin (this study) but not to hypocretin in the presence of TTX (Li et al., 2002), or the arcuate NPY cells that show the opposite profile, with a direct response only to hypocretin. Second, dynorphin may act on different cells than hypocretin acts in target regions for hypocretin axons; corelease could lead ultimately to synergistic actions if hypocretin exerted excitatory actions on postsynaptic neurons, and dynorphin attenuated the inhibitory synaptic input to the same cells. We found this second mechanism in the arcuate nucleus NPY neuron, a synaptic target for hypocretin axons (Horvath et al., 1999) and a cell type that plays a positive role in food intake and energy balance. In NPY cells, hypocretin evoked a direct inward current resulting in an increased spike frequency, and dynorphin attenuated the inhibitory innervation of the NPY cells. Similarly, neurons of the tuberomammillary nucleus are excited by hypocretin (Eriksson et al., 2001), and the inhibitory synaptic input to these cells is reduced by dynorphin (Eriksson et al., 2004). A third possibility is that the rate of desensitization is different for the two peptides, with dynorphin desensitizing more rapidly than hypocretin; thus, at low spike frequencies, the probability of dynorphin reducing activity is greater, whereas at continued or higher frequencies of corelease, the inhibitory effects of dynorphin would desensitize, and the excitatory effects of hypocretin would continue. This is the response found when we tested the nearby $\mathrm{MCH}$ neurons in voltage clamp. These neurons receive direct innervation from hypocretin neurons (Elias et al., 1998; Peyron et al., 1998; Guan et al., 2002; van den Pol et al., 2004), and with repeated costimulation of dynorphin plus hypocretin, the response shifted from an inhibitory outward current to an excitatory inward current. Thus, hypothetically, slow or initial firing of the hypocretin neuron might be less excitatory, whereas with repeated firing, the response of the $\mathrm{MCH}$ cell may shift toward excitation. A similar response profile was found when hypocretin cells were tested in current clamp, with the initial coapplication resulting in a reduction of spike frequency, but later coapplications increasing the spike frequency. A fourth possibility is that dynorphin may be released by hypocretin axons and then attenuate release of hypocretin by presynaptic inhibition; this would be consistent with our finding that, acting by a presynaptic mechanism, dynorphin inhibited synaptic transmission from unidentified excitatory axons synapsing on hypocretin cells. Hypocretin cells have been suggested previously to contain glutamate as a fast-acting transmitter (Abrahamson and Moore, 2001; Rosin et al., 2003); therefore, some of the axons releasing glutamate could be hypocretin axons.

Hypocretin evoked a greater magnitude effect than dynorphin at equimolar concentrations, potentially favoring hypocretin excitation. It is also possible that expression levels of the two peptides are independently regulated. Thus, environmental conditions favoring arousal might lead to an increase in the relative levels of synthesized hypocretin compared with dynorphin, or vice versa. Furthermore, the magnitude of the dynorphinmediated inhibitory effect relative to the excitatory actions of hypocretin would be dependent on the relative concentrations of the two peptides released by the presynaptic axon. Although there are inherent caveats in comparing relative expression levels based on the use of immunocytochemistry, several dynorphin antisera gave weak staining of hypocretin neurons, whereas several hypocretin antisera gave strong immunostaining. Thus, one can speculate that hypocretin may be released at greater concentrations than dynorphin. This might also favor the excitatory actions of hypocretin. The relative synthesis, or extracellular peptidase degradation, of the two peptides may be additional mechanisms whereby the excitatory actions of hypocretin relative to the inhibitory actions of dynorphin may be modulated.

Together, the data here suggest that the two coexpressed peptides with opposite actions can exert several different permutations of effect that are dependent on the target neuron. These responses range from a direct response only to hypocretin (NPY cell), a direct response only to dynorphin (hypocretin cell), or a direct response to both peptides ( $\mathrm{MCH}$ cell). The different responses may further be dependent on ongoing activity of other synaptic inputs to the target neurons, and modulation of these other inputs either presynaptically or postsynaptically may be activity dependent. For instance, dynorphin is more likely to have an effect in blocking GABA inhibition at NPY cells under conditions where GABA is being released. These results suggest that dynorphin release from hypocretin cells could potentially enhance arousal (Hagan et al., 1999) or modulate food intake (Yamanaka et al., 2003) by working synergistically with hypocretin, as found in NPY cells, or could serve to dampen response to low levels of transmitter release but allowing excitation to grow stronger with high levels of activity of hypocretin neurons, as found in the $\mathrm{MCH}$ or hypocretin cell. Similarly, other neurons in the brain, both within and outside the hypothalamus, may also co- 
express a variety of neuropeptides (Kofitsch et al., 1985; Hokfelt et al., 1986). The responses of target neurons of the hypocretin system suggest that costimulation of two neuropeptides of opposite valence can generate different actions depending on the specific target neuron.

\section{References}

Abrahamson EE, Moore RY (2001) The posterior hypothalamic area: chemoarchitecture and afferent connections. Brain Res 889:1-22.

Acuna-Goycolea C, van den Pol AN (2005) Peptide YY(3-36) inhibits both anorexigenic proopiomelanocortin and orexigenic neuropeptide $\mathrm{Y}$ neurons: implications for hypothalamic regulation of energy homeostasis. J Neurosci 25:10510-10519.

Acuna-Goycolea C, Li Y, van den Pol AN (2004) Group III metabotropic glutamate receptors maintain tonic inhibition of excitatory synaptic input to hypocretin/orexin neurons. J Neurosci 24:3013-3022.

Alreja M, Aghajanian GK (1993) Opiates suppress a resting sodiumdependent inward current and activate an outward potassium current in locus ceruleus neurons. J Neurosci 13:3525-3532.

Borowsky B, Durkin MM, Ogozalek K, Marzabadi MR, DeLeon J, Lagu B, Heurich R, Lichtblau H, Shaposhnik Z, Daniewska I, Blackburn TP, Branchek TA, Gerald C, Vaysse PJ, Forray C (2002) Antidepressant, anxiolytic and anorectic effects of a melanin-concentrating hormone- 1 receptor antagonist. Nat Med 8:825-830.

Broberger C, De Lecea L, Sutcliffe JG, Hokfelt T (1998) Hypocretin/orexinand melanin-concentrating hormone-expressing cells form distinct populations in the rodent lateral hypothalamus: relationship to the neuropeptide $\mathrm{Y}$ and agouti gene-related protein systems. J Comp Neurol 402:460-474.

Castillo PE, Salin PA, Weisskopf MG, Nicoll RA (1996) Characterizing the site and mode of action of dynorphin at hippocampal mossy fiber synapses in the guinea pig. J Neurosci 16:5942-5950.

Chemelli RM, Willie JT, Sinton CM, Elmquist JK, Scammel T, Lee C, Richardson JA, Williams SC, Xiong Y, Kisanuki Y, Fitch TE, Nakazato M, Hammer RE, Saper CB, Yanagisawa M (1999) Narcolepsy in orexin knockout mice: molecular genetics of sleep regulation. Cell 98:437-451.

Chou TC, Lee CE, Lu J, Elmquist JK, Hara J, Willie JT, Beuckmann CT, Chemelli RM, Sakurai T, Yanagisawa M, Saper CB, Scammell TE (2001) Orexin (hypocretin) neurons contain dynorphin. J Neurosci 21:RC168(1-6).

Crocker A, Espana RA, Papadopoulou M, Saper CB, Faraco J, Sakurai T, Honda M, Mignot E, Scammell TE (2005) Concomitant loss of dynorphin, NARP, and orexin in narcolepsy Neurology 65:1184-1188.

de Lecea L, Kilduff TS, Peyron C, Gao X, Foye PE, Danielson PE, Fukuhara C, Battenberg EL, Gautvik VT, Bartlett FS 2nd, Frankel WN, van den Pol AN, Bloom FE, Gautvik KM, Sutcliffe JG (1998) The hypocretins: hypothalamus-specific peptides with neuroexcitatory activity. Proc Natl Acad Sci USA 95:322-327.

Desjardins GC, Brawer JR, Beaudet A (1990) Distribution of mu, delta, and kappa opioid receptors in the hypothalamus of the rat. Brain Res 536:114-123.

Ding Y, Kaneko T, Momura S, Mizuno N (1996) Immunohistochemical localization of u-opioid receptors in the CNS of the rat. J Comp Neurol 367:375-402.

Elias CF, Saper CB, Maratos-Flier E, Tritos NA, Lee C, Kelly J, Tatro JB, Hoffman GE, Ollmann MM, Barsh GS, Sakurai T, Yanagisawa M, Elmquist JK (1998) Chemically defined projections linking the mediobasal hypothalamus and the lateral hypothalamic area. J Comp Neurol 402:442-459.

Eriksson KS, Sergeeva OA, Brown RE, Haas HL (2001) Orexin/hypocretin excites the histaminergic neurons of the tuberomammillary nucleus. J Neurosci 21:9273-9279.

Eriksson KS, Sergeeva OA, Selbach O, Haas HL (2004) Orexin (hypocretin)/ dynorphin neurons control GABAergic inputs to tuberomammillary neurons. Eur J Neurosci 19:1278-1284.

Fallon JH, Leslie FM (1986) Distribution of dynorphin and enkephalin peptides in the rat brain. J Comp Neurol 249:293-336.

Freund TF, Buzsaki G (1996) Interneurons of the hippocampus. Hippocampus 6:347-470.

Fu LY, Acuna-Goycolea C, van den Pol AN (2004) Neuropeptide Y inhibits hypocretin/orexin neurons by multiple presynaptic and postsynaptic mechanisms: tonic depression of the hypothalamic arousal system. J Neurosci 24:8741-8751.

Gao XB, van de Pol AN (1999) Neurotrophin-3 potentiates excitatory GABAergic synaptic transmission in cultured developing hypothalamic neurons of the rat. J Physiol 518:81-95.

Georgescu D, Zachariou V, Barrot M, Mieda M, Willie JT, Eisch AJ, Yanagisawa M, Nestler EJ, DiLeone RJ (2003) Involvement of the lateral hypothalamic peptide orexin in morphine dependence and withdrawal. J Neurosci 23:3106-3111.

Grudt TJ, Williams JT (1993) kappa-Opioid receptors also increase potassium conductance. Proc Natl Acad Sci USA 90:11429-11432.

Guan JL, Uehara K, Lu S, Wang QP, Funahashi H, Sakurai T, Yanagizawa M, Shioda S (2002) Reciprocal synaptic relationships between orexin- and melanin-concentrating hormone-containing neurons in the rat lateral hypothalamus: a novel circuit implicated in feeding regulation. Int J Obes Relat Metab Disord 26:1523-1532.

Hagan JJ, Leslie RA, Patel S, Evans ML, Wattam TA, Holmes S, Benham CD, Taylor SG, Routledge C, Hemmati P, Munton RP, Ashmeade TE, Shah AS, Hatcher JP, Hatcher PD, Jones DN, Smith MI, Piper DC, Hunter AJ, Porter RA, et al. (1999) Orexin A activates locus coeruleus cell firing and increases arousal in the rat. Proc Natl Acad Sci USA 96:10911-10916.

Hara J, Beuckmann CT, Nambu T, Willie JT, Chemelli RM, Sinton CM, Sugiyama F, Yagami K, Goto K, Yanagisawa M, Sakurai T (2001) Genetic ablation of orexin neurons in mice results in narcolepsy, hypophagia, and obesity. Neuron 30:345-354.

Hara J, Yanagisawa M, Sakurai T (2005) Difference in obesity phenotype between orexin-knockout mice and orexin neuron-deficient mice with same genetic background and environmental conditions. Neurosci Lett 380:239-242.

Hokfelt T, Holets VR, Staines W, Meister B, Melander T, Schalling M, Schultzberg M, Freedman J, Bjorklund H, Olson L, Lindh B, Elfvin L, Lundberg JM, Lindgren JA, Samuelsson B, Pernow B, Terenius L, Post C, Everitt B, Goldstein M (1986) Coexistence of neuronal messengers-an overview. Prog Brain Res 68:33-70.

Horvath TL, Peyron C, Diano S, Ivanov A, Aston-Jones G, Kilduff TS, van den Pol AN (1999) Hypocretin (orexin) activation and synaptic innervation of the locus coeruleus noradrenergic system. J Comp Neurol 415:145-159.

Kofitsch G, Zamir N, Helke CJ, Savitt JM, Jacobowitz DM (1985) Corticotropin releasing factor-like immunoreactivity in sensory ganglia and capsaicin sensitive neurons of the rat central nervous system: colocalization with other neuropeptides. Peptides 6:307-318.

Li Y, Gao XB, Sakurai T, van den Pol AN (2002) Hypocretin/orexin excites hypocretin neurons via a local glutamate neuron-A potential mechanism for orchestrating the hypothalamic arousal system. Neuron 36:1169-1181.

Lin L, Faraco J, Li H, Kadotani R, Rogers W, Lin X, Qui X, deJong PJ, Nishino S, Mignot E (1999) The sleep disorder canine narcolepsy is caused by a mutation in the hypocretin (orexin) receptor 2 gene. Cell 98:365-376.

Liu RJ, van den Pol AN, Aghajanian GK (2002) Hypocretins (orexins) regulate serotonin neurons in the dorsal raphe nucleus by excitatory direct and inhibitory indirect actions. J Neurosci 22:9453-9464.

Mansour A, Khachaturian H, Lewis ME, Akil H, Watson SJ (1987) Autoradiographic differentiation of $\mu, \delta$, and $\kappa$ opioid receptors in the rat forebrain and midbrain. J Neurosci 7:2445-2464.

Mansour A, Fox CA, Burke S, Meng F, Thompson RC, Akil H, Watson SJ (1994) $\mathrm{Mu}$, delta, and kappa opioid receptor mRNA expression in the rat CNS: an in situ hybridization study. J Comp Neurol 350:412-438.

Mansour A, Burke S, Pavlic RJ, Akil H, Watson SJ (1996) Immunohistochemical localization of the cloned K1 receptor in the rat CNS and pituitary. Neuroscience 71:671-690.

Nishino S, Ripley B, Overeem S, Lammers GJ, Mignot E (2000) Hypocretin (orexin) deficiency in human narcolepsy. Lancet 355:39-40.

Ogura M, Kita H (2000) Dynorphin exerts both postsynaptic and presynaptic effects in the Globus pallidus of the rat. J Neurophysiol 83:3366-3376.

Peyron C, Tighe DK, van den Pol AN, de Lecea L, Heller HC, Sutcliffe JG, Kilduff TS (1998) Neurons containing hypocretin (orexin) project to multiple neuronal systems. J Neurosci 18:9996-10015.

Peyron C, Faraco J, Rogers W, Ripley B, Overeem S, Charnay Y, Nevsimalova S, Aldrich M, Reynolds D, Albin R, Li R, Hungs M, Pedrazzoli M, Padigaru M, Kucherlapati M, Fan J, Maki R, Lammers GJ, Bouras C, Kucherlapati R, Nishino S, et al. (2000) A mutation in a case of early onset 
narcolepsy and a generalized absence of hypocretin peptides in human narcoleptic brains. Nat Med 6:991-997.

Pinto S, Roseberry AG, Liu H, Diano S, Shanabrough M, Cai X, Friedman JM, Horvath TL (2004) Rapid rewiring of arcuate nucleus feeding circuits by leptin. Science 304:110-115.

Roseberry AG, Liu H, Jackson AC, Cai X, Friedman JM (2004) Neuropeptide Y-mediated inhibition of proopiomelanocortin neurons in the arcuate nucleus shows enhanced desensitization in ob/ob mice. Neuron 41:711-722.

Rosin DL, Weston MC, Sevigny CP, Stornetta RL, Guyenet PG (2003) Hypothalamic orexin (hypocretin) neurons express vesicular glutamate transporters VGLUT1 or VGLUT2. J Comp Neurol 465:593-603.

Sakurai T, Amemiya A, Ishii M, Matsuzaki I, Chemelli RM, Tanaka H, Williams SC, Richardson JA, Kozlowski GP, Wilson S, Arch JR, Buckingham RE, Haynes AC, Carr SA, Annan RS, McNulty DE, Liu WS, Terrett JA, Elshourbagy NA, Bergsma DJ, et al. (1998) Orexins and orexin receptors: a family of hypothalamic neuropeptides and G protein-coupled receptors that regulate feeding behavior. Cell 92:573-585.

Schwartz MW, Woods SC, Porte Jr D, Seeley RJ, Baskin DG (2000) Central nervous system control of food intake. Nature 404:661-671.

Seeley RJ, Woods SC (2003) Monitoring of stored and available fuel by the CNS: implications for obesity. Nat Rev Neurosci 4:901-909.

Shuster SJ, Riedl M, Li X, Vulchanova L, Elde R (2000) The kappa opioid receptor and dynorphin co-localize in vasopressin magnocellular neurosecretory neurons in guinea-pig hypothalamus. Neuroscience 96:373-383.

Sun QQ, Huguenard JR, Prince DA (2001) Neuropeptide Y receptors differentially modulate G-protein-activated inwardly rectifying K+ channels and high-voltage-activated $\mathrm{Ca} 2+$ channels in rat thalamic neurons. J Physiol (Lond) 531:67-79.

Sutcliffe JG, de Lecea L (2002) The hypocretins: setting the arousal threshold. Nat Rev Neurosci 3:339-349.

Svoboda KR, Lupica CR (1998) Opioid inhibition of hippocampal inter- neurons via modulation of potassium and hyperpolarization-activated cation $\left(I_{\mathrm{h}}\right)$ currents. J Neurosci 18:7084-7098.

Thannickal TC, Moore RY, Nienhuis R, Ramanathan L, Gulyani S, Aldrich M, Cornford M, Siegel JM (2000) Reduced number of hypocretin neurons in human narcolepsy. Neuron 27:469-474.

van den Pol AN (1999) Hypothalamic hypocretin (orexin): robust innervation of the spinal cord. J Neurosci 19:3171-3182.

van den Pol AN (2000) Narcolepsy, a neurodegenerative disease of the hypocretin system? Neuron 27:415-418.

van den Pol AN, Gao XB, Obrietan K, Kilduff TS, Belousov AB (1998) Presynaptic and postsynaptic actions and modulation of neuroendocrine neurons by a new hypothalamic peptide, hypocretin/orexin. J Neurosci 18:7962-7971.

van den Pol AN, Ghosh PK, Liu R, Li Y, Aghajanian GK, Gao XB (2002) Hypocretin (orexin) enhances neuron activity and cell synchrony in developing mouse GFP-expressing locus coeruleus. J Physiol (Lond) 541:169-185.

van den Pol AN, Acuna-Goycolea C, Clark KR, Ghosh PK (2004) Physiological properties of hypothalamic MCH neurons identified with selective expression of reporter gene after recombinant virus infection. Neuron 42:635-652.

van den Top M, Lee K, Whyment AD, Blanks AM, Spanswick D (2004) Orexigen-sensitive NPY/AgRP pacemaker neurons in the hypothalamic arcuate nucleus. Nat Neurosci 7:493-494.

Wiley JW, Moises HC, Gross RA, MacDonald RL (1997) Dynorphin A-mediated reduction in multiple calcium currents involves a $G(0)$ alpha-subtype $G$ protein in rat primary afferent neurons. J Neurophysiol 77:1338-1348.

Yamanaka A, Beuckmann CT, Willie JT, Hara J, Tsujino N, Mieda M, Tominaga M, Yagami K, Sugiyama F, Goto K, Yanagisawa M, Sakurai T (2003) Hypothalamic orexin neurons regulate arousal according to energy balance in mice. Neuron 38:701-713. 